\title{
Felelős turizmus, felelős döntéshozók, avagy CSR, ahogy a balatoni turizmusban érintett szereplök látják
}

\author{
Szerzők: Hajmásy Gyöngyi ${ }^{1}$
}

A klímaváltozásnak, valamint az egyre inkább kimerülőben levő természeti erôforrásoknak köszönhetôen növekvő trendet mutat mind a társadalmilag, környezetileg és gazdaságilag felelős turisztikai termékek terjedése, mind az irántuk mutatkozó kereslet. Mivel a turizmus eróteljesen a desztinációk természeti vonzerején alapszik, a környezetvédelem és a környezet megörzése kiemelten fontos. Ugyanakkor a turisztikai vállalkozások felelősek az adott közösségért is, amelyben müködnek. Ennek jegyében megfelelöen kell kezelniük a turizmus természeti környezetre, valamint közösségre gyakorolt hatását. Ez a tanulmány a Balaton régió turizmusában érintett szereplők aktuális CSR-ral kapcsolatos nézőpontját vizsgálja.

Kulcsszavak: Balaton, társadalmi felelősségvállalás, CSR, felelős turizmus.

\section{Bevezetés}

Az utóbbi években a vállalati társadalmi felelősségvállalás (angolul Corporate Social Responsibility, röviden CSR) elméleti háttere és gyakorlati alkalmazása egyre kiemelkedőbb figyelmet kap. Ennek következtében a turisztikai szektorban is egyre több vállalkozás kötelezi el magát a társadalmi felelősségvállalás, illetve a felelós turizmus mellett (GAO et al. 2014). A túlnyomóan természeti és társadalmi erőforrásokra épülő ágazat (FREYGEORGE 2010) elsősorban a környezetvédelmet, a helyi közösség, valamint a szektorban dolgozók érdekeit és jólétét helyezi a felelős múködés középpontjába (GAO et al. 2014, KUCUKUSTA et al. 2013).

A felelős turizmus iránti elkötelezettség csírái a tömegturizmus térhódításának és a környezetre gyakorolt negatív hatásainak köszönhetóen jelentek meg. Nyilvánvalóvá vált ugyanis, hogy az effajta turizmus komoly környezeti károkat okozhat, amennyiben nem kontrollálják megfelelóen. A fenntartható fejlődés kérdésével kapcsolatos viták hatására látott napvilágot 1996-ban a dél-afrikai White Paper (Fehér Papír) "A turizmus fejlesztése és elôsegítése Dél-Afrikában" címmel (FREY-GEORGE 2010). A dokumentum egyértelmúen megfogalmazta, hogy a felelős turizmus Dél-Afrikában nem luxus, hanem szükségszerú. A későbbiekben kidolgozásra került ezzel kapcsolatban a Felelős Turizmus Kézikönyve, illetve a felelős turizmus

${ }^{1}$ PhD hallgató, Pannon Egyetem, hajmasy.gyongyi@gtk.uni-pannon.hu irányelvei is (FREY-GEORGE 2010). Mindezek következményeképp a "Cape Town-i Nyilatkozat"ban fogalmazódott meg a felelős turizmus három alappillére:

- A turizmus fejlődése növeli a környező közösségek életszínvonalát.

- A turizmus fejlődése jobb gazdasági környezetet, üzleti lehetôségeket teremt.

- A turizmus fejlődése növeli a turisták élményét.

A Nyilatkozatban megfogalmazottak teljesüléséhez azonban elengedhetetlen a turizmusban érintett szereplők - szálláshelyek, kormányzati, civil és szakmai szervezetek, helyi közösség tagjai - azaz a köz- és magánszféra közötti együttmúködés (HAPP 2014). Sok esetben azonban a felelős és fenntartható turizmus megvalósulásához a turizmusban érintett szereplők szemléletváltása szükséges (MICHALKÓ 2012).

Az állami és magánszektorbeli kötelezettségvállalás szükségességét hangsúlyozza a 2008ban, az indiai Kerala-ban megrendezett II. Felelős Turizmus a Desztinációkban Nemzetközi Konferencia (Second International Conference on Responsible Tourism in Destinations) (FREY-GEORGE 2010). MATHEW és SREEJESH (2017) szerint a felelős turizmus iránti általános pozitív hozzáállás ellenére a vállalkozások nem szentelnek elegendő időt, és nem fordítanak pénzt a felelős turisztikai kezdeményezések követésére. A felelős turizmushoz kapcsolódó költségek és a kormányzati támogatás hiánya szintén a felelős turizmus terjedésének fóbb korlátai. Pedig, ahogy HAPP (2014) fogalmaz, a felelősségteljes turizmusnak, mely a gazdasági és természeti környezet mellett a társadalmat is 
Lektorált tanulmányok

figyelembe veszi, kulcsfontosságú szerepe van a fenntartható turizmus kialakulásában, és ehhez kapcsolódóan minden szereplőnek meghatározható a saját szerepe, feladata. Ugyanakkor a turisztikai desztinációk helyi lakosai pozitívan nyilatkoztak a felelős turizmusról (MATHEW-SREEJESH 2017). Véleményük szerint a felelős turizmussal kapcsolatos kezdeményezések hozzájárulnak az életminőség javulásához és a desztinációk fenntarthatóságához.

Jelen tanulmány célja, hogy a Balaton régió turizmusában érintett szereplők (köz- és magánszféra érintettjei egyaránt) körében feltérképezze, hogy tisztában vannak-e a társadalmi felelósségvállalás jelentésével és jelentóségével, illetve ehhez kapcsolódóan melyek azok a tevékenységek, esetleges ,,jó gyakorlatok", melyeket már alkalmaznak a térségben.
A szakirodalmi háttér áttekintését követóen azok a tevékenységek kerültek azonosításra, amelyek a társadalmi felelősségvállalás vonatkozásában desztináció szinten értelmezhetóek. Ezekre a tevékenységekre építkezve került sor az elsődleges kutatásra, amelyből kiderül, hogy a felmérésben résztvevő szereplők tisztában vannak a társadalmi felelősségvállalás jelentésével, és fontosnak tartják annak alkalmazását.

\section{A felelôs turizmus fogalmához kapcsolódó definíciók}

Az említett eseményekkel párhuzamosan egyre több kutató érdeklődését keltette fel a felelős turizmus és az ehhez kapcsolódó felelósségteljes irányítás, mely számos meghatározáshoz, definícióhoz vezetett, melyeket az 1. számú táblázat foglal össze.

\section{A felelós turizmushoz kapcsolódó definíciók}

\begin{tabular}{|c|c|c|}
\hline Megnevezés (fogalom) & Definíció & Hangsúlyos elem \\
\hline $\begin{array}{l}\text { Felelös turizmus } \\
\text { (SPENCELEY et al. 2002) }\end{array}$ & $\begin{array}{l}\text { A turisták számára jobb üdülési élményt } \\
\text { nyújtani, és megfelelö üzleti lehetőségeket } \\
\text { biztosítani a helyi vállalkozásoknak } \\
\text { az életminóség javitása érdekében, a } \\
\text { megnövekedett társadalmi-gazdasági elônyök } \\
\text { és a természeti erôforrások megfeleló kezelése } \\
\text { révén. }\end{array}$ & $\begin{array}{l}\text { - versenyelöny biztositása } \\
\text { - a turizmus hatásainak mérése és } \\
\text { nyomon követése } \\
\text { - közösségek bevonása és gazdasági } \\
\text { kapcsolatok kialakítása } \\
\text { - természeti, gazdasági, társadalmi és } \\
\text { kulturális sokszinuuség } \\
\text { - helyi eróforrások fenntartható módon való } \\
\text { használata }\end{array}$ \\
\hline $\begin{array}{l}\text { Fenntartható turizmus } \\
\text { (MIDDLETON 1998) }\end{array}$ & $\begin{array}{l}\text { Ideális látogatószám meghatározása egy } \\
\text { adott desztinációban, annak érdekében, } \\
\text { hogy az ott zajló tevékenységek a jövőben } \\
\text { is fenntarthatóak legyenek anélkül, hogy az } \\
\text { káros hatással lenne az adott desztináció } \\
\text { környezetének minooségére. }\end{array}$ & $\begin{array}{l}\text { - erôforrások felelôs használata és megôrzése a } \\
\text { jelenlegi és jövőbeni generációk számára }\end{array}$ \\
\hline $\begin{array}{l}\text { Etikus turizmus } \\
\text { (WEEDEN 2001) }\end{array}$ & $\begin{array}{l}\text { Olyan koncepció, amely túlmutat a } \\
\text { fenntarthatóság három pillérén. Felismeri, } \\
\text { hogy a turistáknak és a turisztikai } \\
\text { vállalkozásoknak is felelösséget kell vállalniuk } \\
\text { magatartásukért, és a stakeholderek minden } \\
\text { egyes csoportjának azonos súllyal kell bírnia } \\
\text { a döntéshozatali folyamatokban. }\end{array}$ & $\begin{array}{l}\text { - turisták és turisztikai vállalkozások erkölcsi } \\
\text { felelóssége a tetteikért }\end{array}$ \\
\hline $\begin{array}{l}\text { Ökoturizmus } \\
\text { (FENNELL 2001) }\end{array}$ & $\begin{array}{l}\text { Viszonylag zavartalan és háboritatlan } \\
\text { természeti területekre irányuló turizmus, } \\
\text { amelynek fö célja a vadon élő állatok és } \\
\text { növények megismerése, megcsodálása. }\end{array}$ & $\begin{array}{l}\text { - környezet megóvása } \\
\text { - közösségek részvételének hangsúlyozása } \\
\text { - egyszerre fenntartható és nyereséges }\end{array}$ \\
\hline $\begin{array}{l}\text { Örökségturizmus } \\
\text { (www.planeta.com) }\end{array}$ & $\begin{array}{l}\text { A turizmus azon ága, amely a természeti } \\
\text { és épített környezet megóvását egyaránt } \\
\text { fontosnak tartja. }\end{array}$ & $\begin{array}{l}\text { - helyi természeti környezet és a helyi } \\
\text { kulturális örökség tiszteletben tartása }\end{array}$ \\
\hline $\begin{array}{l}\text { Alternatív turizmus } \\
\text { (KRIPPENDORF 1987) }\end{array}$ & $\begin{array}{l}\text { Az alternatív turizmus résztvevói arra } \\
\text { törekednek, hogy kerüljék a tömegturisztikai } \\
\text { helyszíneket, valamint, hogy egymástól is a } \\
\text { lehetô legnagyobb távolságra legyenek. }\end{array}$ & $\begin{array}{l}\text { - egyedülálló és autentikus élmények a helyi } \\
\text { közösségbe és környezetbe való bekapcsolódás } \\
\text { révén }\end{array}$ \\
\hline
\end{tabular}

Forrás: saját szerkesztés SPENCELEY et al. (2002), MIDDLETON (1998), WEEDEN (2001), FENNELL (2001), www.planeta.com, KRIPPENDORF (1987) és FREY-GEORGE (2010) alapján 
A megközelítések nem szinonímái egymásnak, azonban közös pontjuk, hogy a negatív társadalmi, gazdasági és környezeti hatások minimalizálására irányulnak, miközben a turizmus pozitív hatásait maximalizálni igyekeznek a fejlődés érdekében.

Jelen kutatás szempontjából az első - vagyis a felelôs turizmus - definíciót tekintem irányadónak, mert ahogy már korábban is említésre került, a gazdasági és természeti környezet mellett a társadalmat is figyelembe veszi, ugyanakkor a felelősségteljes turizmus megvalósulása elősegíti a fenntartható turizmust (HAPP 2014). A fenntartható turizmusnak, ahogy MICHALKÓ (2012) fogalmaz: „hosszú távon ökológiailag elviselhetőnek, gazdaságilag kivitelezhetőnek, etikai és szociális szemszögból a helyi lakosságra nézve méltányosnak kell lennie".

A többi meghatározás ennél szúkebb körben értelmezhető, mivel elsősorban a látogatószámra, az attrakciók megóvására, valamint a természeti környezet megismerésére és megóvására irányulnak. Az ökoturizmust sok esetben azonosítják a felelős, illetve a fenntartható turizmussal, azonban az említett fogalmak nem szinonímái egymásnak. A jellemzően védett természeti területekhez kötődô ökoturizmus középpontjában a természet áll, mely szorosan kapcsolódik a turizmushoz, az adja annak alapját (HAPP 2014, MAGYAR-SULYOK 2014). Ezért is kiemelkedő a környezet és a természeti értékek, mint utazást kiváltó vonzerók védelme, melyhez szorosan kapcsolódik a bevételteremtés és a helyiek bevonása mellett a környezeti nevelés is. (MICHALKÓ 2012, MAGYARSULYOK 2014).

\section{Társadalmi felelősségvállalás}

A felelősségteljes turizmus menedzsment szorosan kapcsolódik a vállalati társadalmi felelősségvállaláshoz (FREY-GEORGE 2010). Napjainkban a társadalmi felelősségvállalás kapcsán előtérbe kerül a „hármas pillér” (Triple Bottom Line) által hangsúlyozott koncepció, amely szerint a vállalatoknak a nyereség maximalizálásán túlmutatóan társadalmi és környezeti érdekeket is figyelembe kell venniük múködésük során (FATMA 2016, REID et al. 2017, TSAI et al. 2012).

$\mathrm{Az}$ egyik legismertebb és legelterjedtebb definíció szerint a CSR „olyan koncepció, amely révén a vállalatok önkéntes alapon integrálják a társadalmi és környezeti megfontolásokat üzleti folyamataikba és az érintettekkel folytatott interakcióikba" (COMMISSION OF THE EUROPEAN COMMUNITIES 2001:6). Egy másik megfogalmazás szerint a CSR ,az üzleti vállalkozások folyamatos elkötelezettsége az etikus viselkedés mellett és amel- lett, hogy hozzájáruljon a gazdasági fejlődéshez, miközben javítja az alkalmazottak és családtagjaik, valamint a helyi közösségek és a társadalom egészének életkörülményeit" (WORLD BUSINESS COUNCIL FOR SUSTAINABLE DEVELOPMENT 1999:3).

A CSR koncepcióját azonban a Freeman által megfogalmazott stakeholder-elmélet írja le leginkább. Az érintett (stakeholder) megközelítés szerint a sikeres üzleti múködés kulcsa a vállalat érintettjeinek ismerete. Az elmélet szerint az érintettek körébe tartoznak mindazok, akiknek hatása lehet a vállalatra, illetve akikre a vállalat eredménye hatással lehet. Ez alapján a stakeholderek csoportjába sorolhatók például az alkalmazottak, a közösség tagjai, a beszállítók és a fogyasztók (BENAVIDES-VELASCO et al. 2014, TSAI et al. 2012, KUCUKUSTA et al. 2013, THEODOULIDIS et al. 2017).

Ahogy a különböző definíciók alapján látható, a társadalmi felelősségvállalás több szereplőt érint, sikeres alkalmazásához pedig elengedhetetlen az érintett szereplők közötti együttmúködés (FREYGEORGE 2010).

\section{A turizmus jelentôsége Magyarországon és a Balaton régióban}

Jelen tanulmány desztináció szinten vizsgálja a társadalmi felelősségvállalás, illetve felelős turizmus kérdését. A kutatás középpontjában a Balaton régió, valamint a régióban múködő turisztikai döntéshozatalban érintett szereplők nézőpontja áll. Előtte azonban fontos bemutatni a turizmus hazai gazdaságban betöltött szerepét, valamint jelentóségét az adott régióban.

Annak ellenére, hogy mind nemzetközi, mind hazai viszonylatban a turizmus a gazdaság vezető ágazatai közé tartozik, számos negatív hatással bír, mint például a környezetszennyezés vagy a növekvő társadalmi egyenlőtlenségek. Ennek következtében egyre több turisztikai szereplőben tudatosul, hogy a tömegturizmus helyett olyan alternatív turisztikai formákra van szükség, mint például a felelős turizmus (PUCZKÓ-RÁTZ 2001). A felelős turizmus szemléletét a hosszú távú gondolkodás jellemzi, a fejlesztések tudatos és átfogó koncepció mentén történnek, összhangot teremtve a desztináció természeti, kulturális és gazdasági adottságaival (PUCZKÓ-RÁTZ 2001). Fokozottan figyelembe veszi a desztináció értékeit, és előnyben részesíti a helyi kézmúves termékeket. A hazai turizmusban is egyre többször hallani a felelősségvállalás, fenntarthatóság fogalmakat, azonban a magyarországi felelős turizmus ennek ellenére még gyerekcipőben jár. 
Lektorált tanulmányok

A turisztikai iparágak mind globális, mind hazai szinten jelentős mértékben járulnak hozzá a gazdaság teljesítményéhez. 2015-ben globális szinten közel 284 millió munkahelyet teremtett az ágazat, és megközelítőleg 7,2 billió dollárnyi bevételt generált a világgazdaság számára (REID et al. 2017). A turisztikai iparág a magyar gazdaság esetében is jelentős súllyal bír. 2013 óta folyamatosan nő az ágazat teljesítménye. A hazai turizmusban múködô vállalkozások közel 193 ezer főt foglalkoztattak 2016-ban. A magyarországi desztinációk mind belföldi, mind külföldi viszonylatban egyre népszerúbb úti célnak számítanak. Ezzel párhuzamosan emelkedtek a turisztikai célú bevételek is, a magyar lakosság több mint 309 milliárd forintot költött többnapos belföldi utazásokra. A hazánkba látogató külföldiek esetében pedig ez a szám megközelítóleg 1725 milliárd forintnyi bevételt jelent (KSH 2016a).

A tanulmány szempontjából fontos külön kiemelni a Balaton, mint turisztikai régió (kiemelt fejlesztési térség) gazdasági teljesítményét. A Balaton a főváros után hazánk második legnépszerúbb desztinációja, évente több millió belföldi és külföldi turista keresi fel. A régió jelentóségét mutatja az is, hogy 2014-ben a balatoni turisztikai vállalkozások együttes nettó árbevétele meghaladta a 64 milliárd forintot, amely az országos érték 3,0\%át jelentette (KSH 2016b). 2014-ben mintegy 2796 turisztikai vállalkozás múködött a régióban, amely egyben azt is jelenti, hogy a Magyarországon múködő turisztikai vállalkozások 5,2\%-a a régióban található. Szintén a turizmus térségbeli fontosságát jelzi, hogy 2014-ben a régió 179 települése közül 144 területén múködött turisztikai vállalkozás, melyek többsége a mikrovállalkozások körébe tartozik (KSH 2016b).

\section{A társadalmi felelôsségvállalás jelentősége a turizmusban}

Az alapvetóen természeti és társadalmi környezetre épüló turizmus amellett, hogy jelentős mértékben hozzájárul a gazdaság teljesítményéhez, számos negatív hatással bír. A népszerú attrakciók, illetve desztinációk (például a világörökségi helyszínek) turisták tömegeit vonzzák, ezáltal növelve az egyes térségek ökológiai lábnyomát (GROSBOIS 2012). Mindemellett jelentős a turizmusban múködô vállalkozások környezetre gyakorolt hatása is. Ide sorolható a klímaváltozás, a légszennyezés, a zajszennyezés és a hulladékgazdálkodás kérdése. (LI et al. 2017, GROSBOIS 2012, SINGH et al. 2014, PRUD'HOMME-RAYMOND 2013) Társadalmigazdasági kérdések esetén elsôsorban a növekvó társadalmi egyenlótlenségek írhatók a turizmus számlájára (PUCZKÓ-RÁTZ 2001).
Mindezen problémák felismerésének hatására egyre több turisztikai vállalkozás épít be valamilyen CSR tevékenységet a mindennapi múködésébe. Ezek fó motivációja a környezetvédelem és a zöld megoldások által realizálható költségmegtakarítás (BOWE 2005, DODD et al. 2001, LEVY-PARK 2011). A zöld megoldásoknak azonban nemcsak a költségcsökkentés terén van jelentős szerepük. Növekvő trendet mutat a környezettudatos utazók számának növekedése, akiknek fontos, hogy utazásaik során megtapasztalhassák a felelős turizmus nyújtotta lehetőségeket, amelyek az utazási döntéseik meghozatalakor is szerepet játszanak (LI et al. 2017).

A CSR alkalmazása továbbá versenyelőnyt biztosít, és segíti a vendégelégedettség növelését. A vendégelégedettség növelése mellett az alkalmazottak elégedettségének növelésében is jelentós szerepet játszik, valamint segít az alkalmazottak motiválásában, megtartásában és az új munkaerő toborzásában (CHAN et al. 2014, BEREZAN et al. 2013, LEVY-PARK 2011, KIM et al. 2017).

\section{A kutatás módszertana}

Empirikus kutatásom során a Balaton régió turizmusában érintett szereplők társadalmi felelősségvállalással kapcsolatos nézőpontját vizsgáltam kérdôives megkérdezés segítségével. Arra kerestem a választ, hogy a régió turizmusában érintett szereplők, hogy vélekednek a társadalmi felelősségvállalásról, tisztában vannak-e a fogalom jelentésével, véleményük szerint kik azok a szereplók, akiknek desztináció szinten meghatározó szerepe van a társadalmi felelősségvállalásban, hogyan értékelik az egyes - desztináció szinten is értelmezhetó - CSR tevékenységeket általánosságban, valamint konkrétan a régióra vonatkozóan, milyen fejlesztések valósultak már meg a CSR jegyében és milyen jövőbeni fejlesztéseket terveznek, illetve vélnek szükségesnek, fontosnak.

A mintavétel 2018 januárjában történt a veszprémi Pannon Egyetemen múködő Balatoni Turisztikai Kutatóintézet (BATUKI) 2018. januári szakmai panelének részeként. A BATUKI 2015 őszén kezdte meg múködését a veszprémi Pannon Egyetem Gazdaságtudományi Karán. A Kutatóintézet figyelemmel kíséri a balatoni turizmus alakulását, hogy naprakész információval lássa el a térség turizmusában érintett szereplőket. Ugyanakkor a térség turizmusában meghatározó szereplók véleménye is megkérdezésre kerül évente 3 alkalommal (januárban, májusban és szeptemberben) a Balatoni Turizmus-barométer keretében. A megkérdezettek értékelik az elóző időszak turizmusát, illetve megosztják várakozásaikat a követ- 
kező időszakkal kapcsolatban. Mindezek mellett minden panelnek részét képezi még egy-egy aktuális témára fókuszáló kérdéssorozat is, például a társadalmi felelősségvállalás, overtourism (túlturizmus/túlzott turistaáradat) jelenségével kapcsolatban².

A mintavételi alapot tehát a BATUKI adatbázisában található, balatoni turizmusban érintett szereplők elérhetőségei képezték. A kérdőív elektronikus formában került kiküldésre az adatbázisban szereplók részére. Az adatbázisban összesen 158 balatoni turizmusban érintett elektronikus elérhetősége szerepel. Ezek közül 58 TDM szervezet, 69 önkormányzat, 11 szálláshely, 3 szakmai szövetség, illetve szakmai szervezet és 17 egyéb kategóriába sorolható turisztikai szerepló van. Az adatbázisról elmondható, hogy a részvétel önkéntes és anonim válaszadáson alapul, valamint az is hogy a tagok száma folyamatosan változik. Mivel az elérhetôségek többsége a feliratkozott szereplók mellett a publikus felületekról összegyúitött adatokból származik, így az egyes panelek esetében alacsony válaszadási arány jellemző. Mindezek következtében a BATUKI hosszú távú célként fogalmazta meg egy állandó panel kialakítását.

\section{A válaszadók szervezet/vállalkozás típus szerinti megoszlása}

1. ábra

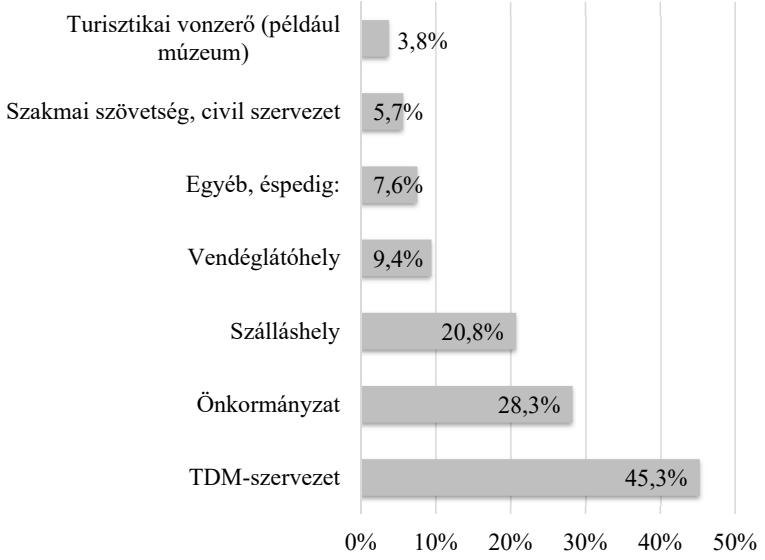

Forrás: saját szerkesztés kérdőíves megkérdezés alapján

A jelen tanulmányhoz készített kérdőívet összesen 53, a balatoni turizmusban érintett szervezetet, vállalkozást irányító szakember töltötte ki. Mivel egy szervezet vezetôje több vállalkozásban lehet érdekelt, így a válaszadásnál több válasz megjelölése is lehetséges volt. Például egy település első embere

2 http://www.gtk.uni-pannon.hu/batuki/ nemcsak az önkormányzat révén lehet érdekelt a turizmusban, hanem mint TDM-szervezeti tag is, mivel több esetben az önkormányzat tagja, fenntartója a helyi TDM-szervezetnek. Így a kérdésre 53 válaszadótól összességében 64 válasz érkezett arra vonatkozóan, hogy milyen szervezetet, vállalkozást képvisel (1. ábra).

A mintában szereplő válaszadók között a TDMszervezetek vezetői vannak többségben (45,3\%). Óket követik a polgármesterek (önkormányzatok), valamint a szálláshelyek üzemeltetói $(28,3 \%$, illetve $20,8 \%$ ). A mintában szerepelnek még vendéglátóhelyek $(9,4 \%)$, szakmai szövetségek és civil szervezetek képviselői $(5,7 \%)$, valamint turisztikai vonzerőt üzemeltetó vállalkozások (3,8\%). Az egyéb kategóriába a válaszadók $7,6 \%$-a tartozik, melyek a következők: Nemzeti Park vezetője, egy térségben múködő lovarda irányítója, a Balaton Világörökségéért Alapítvány, valamint egy egyesületi vezető.

A válaszadók múködési területét tekintve elmondható, hogy elsősorban a keleti régióban múködő vállalkozások, illetve szervezetek vannak többségben. Ahogy a válaszadók megoszlásából is látszik, a minta nem reprezentatív, így a kutatás eredményei csak a válaszadókra fogalmazhatóak meg. A kutatás korlátjának tekinthetố a válaszadók kis mintamérete, amely mélyebbre ható, alaposabb statisztikai elemzéseket nem tett lehetóvé. Ennek következtében a kapott válaszok alapján általánosítani ugyan nem lehet, de a kapott eredmények további vizsgálatok kiváló alapját képezhetik.

\section{Kutatási eredmények}

A kérdőíves felmérés során elsőként arra kerestem a választ, hogy a szereplők mennyire vannak tisztában azzal, mit jelent a társadalmi felelósségvállalás. A válaszadók a 2. ábrán látható szófelhôben szereplő fogalmakat társították leginkább a társadalmi felelősségvállalás fogalmához.

\section{2. ábra}

\section{kapcsolt fogalmak}

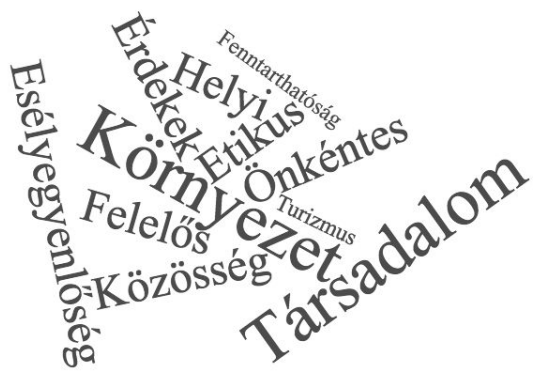

Forrás: saját szerkesztés kérdőíves megkérdezés alapján 
Lektorált tanulmányok

A válaszadók többsége szerint a társadalmi felelósségvállalás leginkább környezettudatosságot és környezettudatos múködést jelent. A környezet mellett ugyanakkor a társadalom és a társadalommal kapcsolatos kérdések is megjelennek. Ehhez kapcsolódóan a válaszadók közül többen említették a társadalom életszínvonalának javítását, a civil élet fejlesztését, nyitottságot a társadalmi problémákra, valamint a társadalmi, szociális feladatok ellátásában és problémák megoldásában való részvételt. Az etikus magatartást és a tiszta versenyt is többen említették, amely a törvényi előírásoknak megfelelő múködést követel.

A gazdasági érdekek mellett többen említették a közösség és a különböző érdekek összehangolásának fontosságát, miszerint a CSR jegyében figyelembe kell venni, és összhangba kell hozni a társadalom és az érintettek (üzletfelek, beszállítók, alkalmazottak, részvényesek) érdekeit. A válaszadók többsége úgy véli, hogy a CSR kötelezettségeken túli önkéntes szerepvállalás, melyben fontos szerepe van a helyi értékek támogatásának és a helyi lakosság turizmusba való bevonásának, továbbá része a folyamatos kapcsolattartás a helyiekkel és képzés az ott élók számára, mely összhangban van a korábbiakban említett közösségi érdekek öszszehangolásával.

Néhányan említették a turizmusból származó előnyök és hátrányok megfelelő kezelését, a felelős turizmust és annak fontosságát. Néhány válaszadó említette még az esélyegyenlőséget és a felelős bánásmódot. Mindezek következtében a kapott válaszok alapján megállapítható, hogy a válaszok összhangban vannak az elméleti részben korábban megfogalmazott definíciókkal, miszerint a társadalmi felelősségvállalás „olyan koncepció, amely révén a vállalatok önkéntes alapon integrálják a társadalmi és környezeti megfontolásokat üzleti folyamataikba és az érintettekkel folytatott interakcióikba" és nem más mint, „az üzleti vállalkozások folyamatos elkötelezettsége az etikus viselkedés mellett és amellett, hogy hozzájáruljon a gazdasági fejlődéshez, miközben javitja az alkalmazottak és családtagjaik, valamint a helyi közösségek és a társadalom egészének életkörülményeit".

Mivel egy desztináció esetében, így a Balaton régióban is, több szereplő érintett közvetlenül vagy közvetetten a turizmusban, akik között jelen vannak a köz- és a magánszféra képviselöi is, fontos meghatározni azoknak a körét, akik hangsúlyos szerepet töltenek be, illetve kell(ene) betölteniük a felelôs turizmus és ahhoz kapcsolódóan a felelósségteljes irányítás terén. Ehhez kapcsolódóan a megkérdezettek véleményét a 3 . ábra szemlélteti, mely alapján megállapítható, hogy legtöbben a települési önkormányzatokat tartják a legmegha- tározóbb szereplőnek a társadalmi felelősségvállalásban és annak fejlesztésében, de a helyi turisztikai desztinációmenedzsment szervezeteknek is jelentôs szerepet tulajdonítanak. A civil, valamint szakmai szervezetek felelóssége mellett a válaszadók egy része a helyi lakosság szerepét is kiemelte a kérdést illetően.

\section{3. ábra}

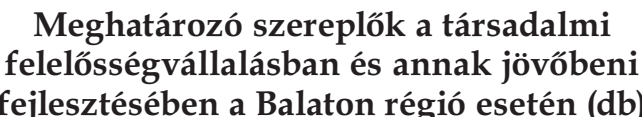

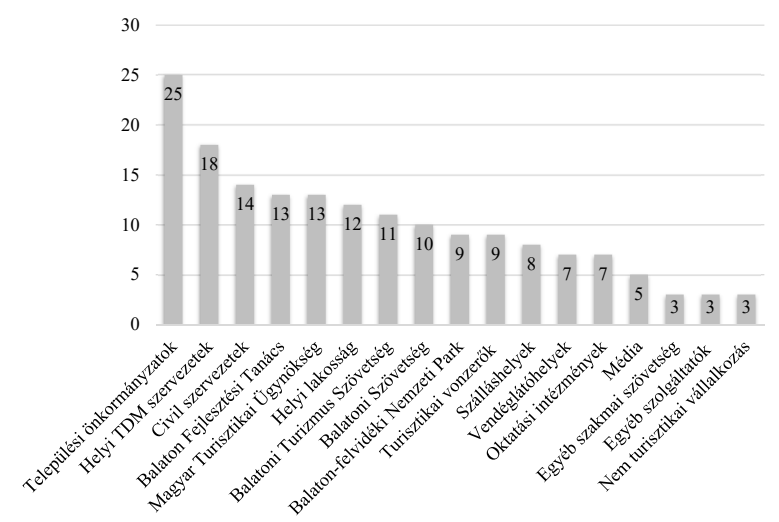

Forrás: saját szerkesztés kérdőíves megkérdezés alapján

A következókben a megkérdezettek véleményének feltárására került sor. Elsóként a társadalmi felelósségvállalással kapcsolatos tevékenységeket általánosságban, majd konkrétan a Balaton régióra vonatkozóan, kellett értékelniük egy 1-tôl 6-ig terjedó skálán (ahol 1=egyáltalán nem ért egyet, $6=$ teljes mértékben egyetért). A kérdésre a mintában szereplő 53 válaszadó közül mindössze 28 fó válaszolt. A társadalmi felelósségvállalással kapcsolatos tevékenységekhez fúződő állításokat és azok általánosságban vett értékelését a 2. táblázat foglalja össze.

A válaszadók leginkább a helyi munkaerő foglalkoztatását tartják fontosnak ( $x=5,54)$. Ezt követik a környezetbarát tevékenységek (például szelektív hulladékgyúités, víz- és energiatakarékos készülékek használata) $(x=5,52)$, majd a helyi kistermelők támogatása és a helyi termékek népszerúsítése $(x=5,5)$. Kiemelten fontosnak tartják még azt is, hogy programszervezés esetén együttmúködjenek a helyi közösségekkel $(x=5,11)$. A kapott eredmények alapján elmondható, hogy az alábbi állítások esetén már megosztottabbak a vélemények, de a válaszadók többsége fontosnak tartja azokat:

- A térségról megfeleló mennyiségú és pontos információ áll a látogatók rendelkezésére. $(x=4,79)$ 


\section{A társadalmi felelôsségvállalással kapcsolatos tevékenységek értékelése (1-6 Likert skálán) általánosságban}

\begin{tabular}{|l|c|}
\hline & Átlag \\
\hline Fontosnak tartom a helyi kistermelök támogatását és a helyi termékek népszerúsitését. & 5,5 \\
\hline Fontosnak tartom a helyi munkaerő foglalkoztatását. & 5,54 \\
\hline $\begin{array}{l}\text { Fontosnak tartom a környezetbarát tevékenységeket (szelektív hulladékgyújtés, víz- és } \\
\text { energiatakarékos készülékek használata). }\end{array}$ & 5,52 \\
\hline $\begin{array}{l}\text { Programszervezés esetén fontosnak tartom a helyi szervezetekkel, helyi közösségekkel való } \\
\text { együttmúködést. }\end{array}$ & 5,11 \\
\hline A térségrôl megfeleló mennyiségú és pontos információ áll a látogatók rendelkezésére. & 4,79 \\
\hline Ösztönzöm és támogatom az önkéntes, közösségi munkavégzést. & 4,71 \\
\hline $\begin{array}{l}\text { A térség támogatja, és ösztönzi a látogatókat, hogy környezetbarát módon fedezzék fel a vidéket } \\
\text { (kerékpáros turizmus, tömegközlekedés kedvezményes használatának biztositása a turistáknak). }\end{array}$ & 4,71 \\
\hline Fontosnak tartom a helyi közösség rászorulóinak támogatását. & 4,71 \\
\hline $\begin{array}{l}\text { A térség a hátrányos helyzetú látogatók (mozgáskorlátozottak, fogyatékosok) számára is nyújt } \\
\text { programokat. }\end{array}$ & 3,89 \\
\hline $\begin{array}{l}\text { A térség a hátrányos helyzetú látogatók (mozgáskorlátozottak, fogyatékosok) számára is könnyen } \\
\text { elérhetố. }\end{array}$ & 3,82 \\
\hline
\end{tabular}

Forrás: saját szerkesztés kérdőíves megkérdezés alapján

- Fontosnak tartom a helyi közösség rászorulóinak támogatását. $(x=4,71)$

- Ösztönzöm és támogatom az önkéntes, közösségi munkavégzést. $(x=4,71)$

- A térség támogatja és ösztönzi a látogatókat, hogy környezetbarát módon fedezzék fel a vidéket (kerékpáros turizmus, tömegközlekedés kedvezményes használatának biztosítása a turistáknak). $(x=4,71)$

A válaszadók legkevésbé azt tartják fontosnak, hogy a térség a hátrányos helyzetú látogatók (moz- gáskorlátozottak, fogyatékosok) számára is nyújtson programokat, valamint, hogy a desztináció számukra is könnyen elérhető legyen.

Összességében tehát elmondható, hogy a válaszadók általánosságban leginkább a környezetvédelmet és a környezetbarát tevékenységeket vélik fontosnak a társadalmi felelősségvállalással kapcsolatosan. Ez összhangban van a korábban a társadalmi felelősségvállalás fogalmához társuló felvetésekkel, hiszen leggyakrabban ott is a környezetvédelemmel kapcsolatos meghatározások kerültek említésre. Meglepó viszont, hogy bár

\section{A társadalmi felelősségvállalással kapcsolatos tevékenységek értékelése a Balaton régióra vonatkozóan}

\begin{tabular}{|c|c|c|c|c|c|c|}
\hline & 1 & 2 & 3 & 4 & Összes & Átlag \\
\hline $\begin{array}{l}\text { Megfelelő mennyiségú és minóségú információ biztositása a } \\
\text { régióról. }\end{array}$ & 0 & 1 & 17 & 10 & 28 & 3,32 \\
\hline Helyi termékek széles kínálata. & 0 & 2 & 19 & 7 & 28 & 3,18 \\
\hline Helyi munkaeró alkalmazása. & 0 & 1 & 21 & 6 & 28 & 3,18 \\
\hline $\begin{array}{l}\text { Környezettudatos fejlesztések (szelektív hulladékgyújtés, } \\
\text { kerékpárút, megújuló energia használata). }\end{array}$ & 0 & 6 & 18 & 4 & 28 & 2,93 \\
\hline $\begin{array}{l}\text { A hátrányos helyzetú látogatók (mozgáskorlátozottak, } \\
\text { fogyatékosok) számára is könnyen igénybe vehetố programok. }\end{array}$ & 0 & 5 & 22 & 1 & 28 & 2,86 \\
\hline $\begin{array}{l}\text { Könnyú megközelíthetôség a hátrányos helyzetú látogatók } \\
\text { (mozgáskorlátozottak, fogyatékosok) számára is. }\end{array}$ & 0 & 7 & 20 & 1 & 28 & 2,79 \\
\hline $\begin{array}{l}\text { Környezetbarát termékek használata a rendezvények } \\
\text { lebonyolitása során (újratölthetô poharak). }\end{array}$ & 0 & 10 & 15 & 3 & 28 & 2,75 \\
\hline
\end{tabular}

Forrás: saját szerkesztés kérdőíves megkérdezés alapján 
Lektorált tanulmányok

manapság egyre több program szorgalmazza a hátrányos helyzetú látogatók elérését és számukra megfeleló infrastrukturális háttér biztosítását, a válaszadók számára mégis ez a legkevésbé fontos. GONDOS (2017) számos jó gyakorlatot sorakoztat fel írásában, amely a Balaton, mint turisztikai desztináció számára is követendô példaként szolgálhat. Példaként említhetô Kaposvár, ahol átalakították a Virágfürdőt és a Fóteret, valamint turisztikai kisfilmet készítettek, amelyben hallássérültek és siketek számára érthetó módon mutatják be a település értékeit. Kaposvár egyébként 2013-ban ezzel a kezdeményezéssel elnyerte a Kiváló Európai Desztináció (EDEN=European Destinations of ExcelleNce) akadálymentes turizmussal kapcsolatos pályázatát.

Amellett, hogy a tanulmány rávilágít arra, hogy a válaszadók általában mely CSR tevékenységeket tartják fontosnak, jelentős az a kérdés is, hogy konkrétan a Balaton, mint turisztikai úti cél esetében hogyan értékelik az egyes tényezóket. Ennek mérésére egy 4-fokozatú skála szolgált, melyben $1=$ egyáltalán nincs és nem tartom fontosnak, $2=$ nincs, de fontosnak tartom, hogy fejlesszük, $3=$ van, de fejlesztésre szorul, $4=$ =van és jól múködik. A kapott eredményeket a 3. táblázat foglalja össze.

A válaszadók többsége úgy véli, hogy a Balatonról, mint desztinációról megfelelő menynyiségú információ áll a látogatók rendelkezésére $(x=3,32)$, emellett a helyi termékek széles kínálata található meg $(x=3,18)$, valamint jellemzóen helyi munkaerôt alkalmaznak a térségben múködő vállalkozások $(x=3,18)$. A legtöbben a környezetbarát termékek hiányát említették, amelyek nem jellemzik a térségben zajló rendezvények lebonyolítását, pedig a válaszadók szerint fontos lenne annak fejlesztése és alkalmazása. Ezek a válaszok összhangban vannak az elôző kérdésre adott értékelésekkel, melynek során általánosságban kellett meghatározni a CSR tevékenységek jelentóségét.

A CSR tevékenységek értékelése mellett a tanulmány rávilágít arra is, hogy vannak még olyan területek, tevékenységek, amelyek fejlesztésre szorulnak a régióban annak ellenére, hogy 2014 és 2017 között több part menti szervezet, vállalkozás és település valósított meg különböző fejlesztéseket a társadalmi felelősségvállalás jegyében. Ezek többsége az infrastrukturális fejlesztések közé tartozik (például akadálymentesítés; 17 említés), ugyanakkor több helyen valósult meg környezetvédelmi fejlesztés (például napkollektor, szelektív hulladékgyúités; 13 említés), szolgáltatás fejlesztés (például rendezvény hátrányos helyzetúeknek; 8 említés) és infokommunikációs fejlesztés (például akadálymentesített honlap; 7 említés). Néhány esetben a társadalmi felelősségvállaláshoz kapcsolódó termékfejlesztés is megvalósult (például bio ételek; 4 említés). Egy település továbbá kiemelte az alábbi tevékenységeket: kutyabarát helyek megjelölése, népszerúsítése; komposztláda-program a település minden lakosa számára ingyenesen; sportrendezvények szervezésében aktív részvétel; ingyenes szolgáltatások meghirdetése a rendezvényekhez kapcsolódóan. Mindezek mellett egy válaszadó megjelölte a közösség rászoruló tagjainak a támogatását is, melynek keretében közel 100 fő részére biztosítanak meleg étkezést. A kapott válaszok egy része meglepó módon ellentétben van azzal a korábbi értékeléssel, miszerint a válaszadók legkevésbé azt tartották fontosnak, hogy a térség a hátrányos helyzetú látogatók (mozgáskorlátozottak, fogyatékosok) számára is nyújtson programokat, valamint, hogy a desztináció számukra is könnyen elérhetô legyen.

A már megvalósult fejlesztések mellett azonban számos olyan kezdeményezés, jó gyakorlat létezik, amelyek népszerúek és jól múködnek a Balaton régióban. Mindezek mellett vannak olyan, más régiókban múködő tevékenységek, mint például a korábban említett kaposvári minta, amelyeket a Balatonnál is lehetne alkalmazni. A válaszadók véleménye alapján, így az alábbi tényezók jellemeznék a Balaton régiót a társadalmi felelősségvállalás jegyében:

- Helyi termék védjegyek, termelói piacok (kiemelve a Balaton-felvidéki Nemzeti Park és az Éltető Balaton-felvidékért Egyesület munkáját);

- Környezettudatos, fenntartható fejlődés és ahhoz kapcsolódóan ismeretterjesztés és környezetbarát szálláshely fejlesztés (kiemelten a Víz Világnapja);

- Kerékpáros turizmus fejlesztése, ehhez kapcsolódó infrastruktúra fejlesztés és bővítés a háttértelepülések bevonásával;

- Akadálymentesített programok körének bóvítése (kiemelten a balatonfúzfói Fogyatékossággal Élő Emberek és Barátaik Országos Kulturális Fesztiválja) és a hátrányos helyzetú látogatók (mozgáskorlátozottak, fogyatékosok) fogadási feltételeinek javítása;

- Ökológiai szemléletú településfenntartás, például vegyszerek mellózése, illetve a felhasznált mennyiség csökkentése.

A kérdéshez szorosan kapcsolódik az is, hogy ennek eléréséhez a jövőben milyen fejlesztések szükségesek. Ennek kapcsán kiemelték az akadálymentesítés infrastrukturális fejlesztésének szükségességét (például akadálymentes közleke- 
dési lehetőségek), valamint a hátrányos helyzetú látogatók (mozgáskorlátozottak, fogyatékosok) számára a programkínálat bővítését. Fontosnak tartják továbbá a Balaton part védelmét és tisztán tartását.

A környezetvédelmet érintő kérdések a jövőbeni fejlesztéseknél is nagy hangsúlyt kapnak. Többen kívánnak nagyobb hangsúlyt fektetni a környezetbarát közlekedésfejlesztésre (például elektromos autóbuszok) és ehhez kapcsolódóan a kerékpárutak minőségi fejlesztésére, valamint a környezetvédelmi kérdésekben történő oktatásra. Elsősorban a települések polgármesterei emelték ki a vegyszermentes településfenntartást és a szelektív hulladékgyújtés ösztönzését.

A régió vállalkozói tovább népszerúsítenék a helyi kézmúves termékeket, és támogatnák a helyi beszállítói rendszerek kiépülését. Nemcsak a helyi termékeknek, hanem a helyi munkaerő alkalmazásának ösztönzését is fontosnak tartják a jövőben, ezen belül pedig a pályakezdő fiatalok támogatásának kellene komoly figyelmet szentelni.

Az infokommunikációs fejlesztés jegyében öszszehangoltabb és kevésbé széttagolt infokommunikációs felületek megalkotására lenne szükség.

Ahogy láthatjuk nemcsak a jó gyakorlatok és a jelenlegi tevékenységek között kapnak hangsúlyos szerepet a CSR-hoz köthetó tevékenységek, hanem a jövőben is több, reális alapokon nyugvó fejlesztést kívánnak véghezvinni annak jegyében. Ezeknek a fejlesztéseknek a többsége égetó fontosságú, hiszen például az egyre nagyobb népszerúségnek örvendő kerékpáros turizmushoz kapcsolódóan a kerékpárutak, vagyis a Balatoni Bringaút, fejlesztése szükségszerú. A helyi termékek is egyre nagyobb népszerúségnek örvendenek a turisták és helyiek körében egyaránt, így fontos, hogy ezek minél szélesebb körben elérhetővé váljanak, nemcsak a turisták, hanem a helyi vendéglátóegységek számára is, mint alapanyag.

\section{8. Összegzés}

Kutatásom során a Balaton régió turizmusában érintett szereplők társadalmi felelősségvállalással kapcsolatos nézőpontját vizsgáltam kérdőíves megkérdezés segítségével. Arra kerestem a választ, hogy a régió turizmusában érintett szereplők, hogy vélekednek a társadalmi felelősségvállalásról, tisztában vannak-e a fogalom jelentésével, véleményük szerint kik azok a szereplők, akiknek desztináció szinten meghatározó szerepe van a társadalmi felelősségvállalásban, hogyan értékelik az egyes - desztináció szinten is értelmezhető CSR tevékenységeket általánosságban, valamint konkrétan a régióra vonatkozóan, milyen fejleszté- sek valósultak már meg a CSR jegyében és milyen jövőbeni fejlesztéseket terveznek, illetve vélnek szükségesnek, fontosnak.

A társadalmi felelősségvállalás, illetve ahhoz kapcsolódóan a felelős turizmus egyre nagyobb teret hódít, mint a tömegturizmus alternatívája. A tömegturizmus, valamint a turizmus általában, jelentős hatással van az egyes desztinációk életére. A pozitív hatások mellett azonban egyre több negatív hatás is jelentkezik, melyeket felismerve több turizmusban érintett szereplő alkalmaz különféle CSR tevékenységet múködése során. Kutatásomban a Balaton régió, mint hazánk második legnépszerúbb turisztikai célpontjának turizmusában érintett szereplők társadalmi felelősségvállalással kapcsolatos nézőpontját vizsgáltam.

A kutatás alapján elmondható, hogy a régió turizmusában érintett szereplők tisztában vannak a CSR fogalmának jelentésével. Az etikus magatartás és az önkéntes jelző mellett megjelenik a CSR három pillére: a környezet, a társadalom és a gazdaság. A környezettel kapcsolatos CSR tevékenységek elsősorban a környezettudatossághoz, környezetvédelemhez kapcsolódnak. A társadalom esetén az életszínvonal javítása jelenik meg, mint a CSR célja, de fontos tényezője a különbözó érdekek összehangolása is. Mindezek mellett megjelenik a helyi termék és a helyi munkaerő, mint a gazdaság fontos eleme. Mivel a régió esetében több szereplő közvetve vagy közvetetten érintett a turizmusban és annak fejlesztésében, fontos lehatárolni azoknak a szereplőknek a körét, akiknek elsődleges szerepe van a társadalmi felelősségvállalásban és annak jövőbeli fejlesztésében. A kutatás során az derült ki, hogy a résztvevők szerint elsősorban a helyi önkormányzatok és turisztikai desztinációmenedzsment szervezetek feladata a társadalmi felelősségvállalás és annak jövőbeni fejlesztése.

A CSR tevékenységek közül mind általánosságban, mind a régióra vonatkozóan a helyi munkaerő alkalmazását és a helyi termékek kínálatát tartják a legfontosabb tényezőnek. A válaszadók pozitív értékelése kapcsán elmondható, hogy összességében fontosnak tartják a társadalmi felelősségvállalást, melyhez kapcsolódóan több fejlesztés is megvalósult az elmúlt években. Ezek többsége infrastrukturális fejlesztés volt, például akadálymentesítés, de több helyen valósult meg környezetvédelmi- és szolgáltatás fejlesztés is. A már megvalósult kezdeményezések mellett a válaszadók tapasztaltak olyan jó gyakorlatokat, melyek véleményük szerint a Balaton régióban is jól múködnének. A helyi termékek kapcsán kiemelték például a helyi védjegy használatot, illetve a termelői piacok népszerúsítését. A környezettudatos fejlesztés kapcsán fontosnak vélik az ahhoz kapcsolódó ismeretterjesztést, 
oktatást, valamint a környezetbarát szálláshely fejlesztést.

A fentiek ismeretében meghatározhatóak tehát azok az irányvonalak, amelyek mentén fejlődve a térség előrelépéseket tehet a felelós turizmus útján. Olyan jövőbeni fejlesztések javasolhatóak a Balaton régióban, amelyek szem előtt tartják a tudatos és fenntartható fejlesztést, valamint nagy hangsúlyt fektetnek a turisták mellett a településekre és a helyi lakosságra.

\section{Köszönetnyilvánítás}

Jelen publikáció, kutatás az Európai Unió, Magyarország és az Európai Szociális Alap társfinanszírozása által biztosított forrásból jött létre az EFOP-3.6.2-16-2017-00017 azonosítójú "Fenntartható, intelligens és befogadó regionális és városi modellek" címú projekt keretében.

\section{Felhasznált irodalom}

BENAVIDES-VELASCOA, C. A. - QUINTANAGARCÍAB, C. - MARCHANTE-LARA, M. (2014): Total quality management, corporate social responsibility and performance in the hotel industry. International Journal of Hospitality Management. 41. pp. 77-87.

BEREZAN, O. - RAABA, C. - YOOB, M. - LOVEA, C. (2013): Sustainable hotel practices and nationality: The impact on guest satisfaction and guest intention to return. International Journal of Hospitality Management. 34. pp. 227-233.

BOWE, R. (2005): Going green: red stripe, yellow curry and green hotels. Environmental Magazine. 16(1). pp. 52-53.

CHAN, E. S. W. - HON, A. H. Y. - CHAN, W. OKUMUS, F. (2014): What drives employees' intentions to implement green practices in hotels? The role of knowledge, awareness, concern and ecological behaviour. International Journal of Hospitality Management. 40. pp. 20-28.

COMMISSION OF THE EUROPEAN COMMUNITIES (2001): Promoting a European framework for corporate social responsibilities. CEC: Brussels.

DODD, T. H. - HOOVER, L. C. - REVILLA, G. (2001): Environmental tactics used by hotel com-panies in Mexico. International Journal of Hospitality \& Tourism Administration. 1(3/4). pp. 111-127.

FATMA, M. - RAHMAN, Z. - KHAN, I. (2016): Measuring consumer perception of CSR in tourism industry: Scale development and validation. Journal of Hospitality and Tourism Management. 27. pp. 39-48.
FENNELL, D. (2001): A content analysis of ecotourism definitions. Current Issues in Tourism. 4(5). pp. 403-421.

FREY, N. - GEORGE, R. (2010): Responsible tourism management: The missing link between business owners' attitudes and behaviour in the Cape Town tourism industry. Tourism Management. 31. pp. 621-628.

GAO, Y. L. - MATTILA, A. S. (2014): Improving consumer satisfaction in green hotels: The roles of perceived warmth, perceived competence, and CSR motive. International Journal of Hospitality Management. 42. pp. 20-31.

GROSBOIS, D. (2012): Corporate social responsibility reporting by the global hotel industry: Commitment, initiatives and performance. International Journal of Hospitality Management. 31. pp. 896-905.

HAPP E. (2014): Fenntartható turizmus és felelósségvállalás. Gazdaság és Társadalom. 6(1). pp. 90-102.

KIM, H. L. - RHOU, Y. - UYSAL, M. - KWON, N. (2017): An examination of the links between corporate social responsibility (CSR) and its internal consequences. International Journal of Hospitality Management. 61. pp. 26-34.

KRIPPENDORF, J. (1987): The holiday makers: understanding the impact of leisure and travel. Oxford: Butterworth-Heinemann.

KUCUKUSTA, D. - MAK, A. - CHAN, X. (2013): Corporate social responsibility practices in four and five-star hotels: Perspectives from Hong Kong visitors. International Journal of Hospitality Management. 34. pp. 19-30.

LEVY, S. E. - PARK, S.-Y. (2011): An analysis of CSR activities in the lodging industry. Journal of Hospitality and Tourism Management. 18(1). pp. 147-154.

LI, Y. - FANGB, S. - HUANC, T-C. (2017): Consumer response to discontinuation of corporate social responsibility activities of hotels. International Journal of Hospitality Management. 64. pp. 41-50.

MAGYAR ZS. - SULYOK J. (2014): Az ökoturizmus helyzete Magyarországon. Turizmus Bulletin. 16(2). pp. 14-23.

MATHEW, P. V. - SREEJESH, S. (2017): Impact of responsible tourism on destination sustainability and quality of life of community in tourism destinations. Journal of Hospitality and Tourism Management. 31. pp. 83-89.

MICHALKÓ G. (2012): Turizmológia. Akadémiai Kiadó, Budapest.

MIDDLETON, V. (1998): Sustainable tourism - A marketing perspective. Oxford: ButterworthHeinemann.

PRUD'HOMME, B. - RAYMOND, L. (2013): Sustainable development practices in the hos- 
pitality industry: An empirical study of their impact on customer satisfaction and intentions. International Journal of Hospitality Management. 34. pp. 116-126.

PUCZKÓ L. - RÁTZ T. (2001): A turizmus hatásai. Aula Kiadó, Budapest.

REID, S. - JOHNSTON, N. - PATIAR, A. (2017): Coastal resorts setting the pace: An evaluation of sustainable hotel practices. Journal of Hospitality and Tourism Management. 33. pp. 11-22.

SINGH, N. - CRANAGEB, D. - LEEB, S. (2014): Green strategies for hotels: Estimation of recycling benefits. International Journal of Hospitality Management. 43. pp. 13-22.

SPENCELEY, A. - RELLY, P. - KEYSER, H. - WARMEANT, P. - McKENZIE, M. MATABOGE, A. -NORTON,P.-MAHLANGU, S. - SEIF, J. (2002): Responsible tourism manual for South Africa. Department of Environmental Affairs and Tourism.

THEODOULIDIS, B. - DIAZ, D. - CROTTO, F. RANCATI, E. (2017): Exploring corporate social responsibility and financial performance through stakeholder theory in the tourism industries. Tourism Management. 62. pp. 173-188.

TSAI, H. - TSANG, N. K. F. - CHENG, S. K.Y. (2012): Hotel employees' perceptions on cor- porate social responsibility: The case of Hong Kong. International Journal of Hospitality Management. 31(4). pp. 1143-1154.

WEEDEN, C. (2001): Ethical tourism: an opportunity for competitive advantage. Journal of Vacation Marketing. 8(8). pp. 141-153.

WORLD BUSINESS COUNCIL FOR SUSTAINABLE DEVELOPEMENT (1999): Corporate social responsibility: Meeting changing expectations. Geneva.

\section{Internetes források}

GONDOS B. (2017): Turizmus és életminóség kapcsolata a mozgáskorlátozottak körében. https:// kgk.sze.hu/images/dokumentumok/kautzkiadvany2017/Gondos_Kautz_2017.pdf Letöltve: 2018. augusztus 10.

KSH (2016a): Jelentés a turizmus és vendéglátás 2016. évi teljesitményéröl. http://www.ksh.hu/docs/ hun/xftp/idoszaki/jeltur/jeltur16.pdf Letöltve: 2018. április 6.

KSH (2016b): Turizmusgazdaság a Balaton idegenforgalmi régióban. http://www.ksh.hu/docs/hun/ xtp/idoszaki/regiok/veszpremturizmusgazd. pdf Letöltve: 2018. április 6.

www.planeta.com 